\title{
A Halotti beszéd isa szavának kutatástörténete és etimológiája"
}

1. Bevezetés. A Halotti beszéd rövid kis szava, az $\dot{y} / a$ szép karriert futott be etimológiai szakirodalmunkban. Sokan próbálták eredetét kinyomozni, jelentését és funkcióját megfejteni, de úgy tünik, hogy a több évtizedes múltra visszatekintő konszenzus szerint e szavunk igencsak makacsul őrzi titkát. A helyesnek tünő megoldáshoz vezető út felfedezése olykor talán csak a véletlennek köszönhető, mint ahogy ez alkalommal velem történt: egy nagyobb lélegzetü etimológiai tanulmány írása közben sürün kellett forgatnom az általam elérhető vogul és osztják szótárakat; ennek során botlottam bele olyan vogul és osztják adverbiumokba, amelyekben megtalálni véltem e szavunk etimológiai megfelelőit, és ezek révén végül talán sikerült ezen adverbiumegyüttes kialakulásának is a nyomára jutnom. Mielőtt azonban ismertetném, mire jutottam, szükségesnek látom fölidézni a tudománytörténeti előzményeket, azt bemutatandó, hogy a sötétben való tapogatózás milyen tévutakra vezetheti az elszánt kutatót. Az előzmények alapos kiderítésére tett kísérletem meglehetősen nagy bibliográfiát eredményezett, amelynek megismerése bizonyára másokat is segít az $\dot{y} / a$ ügyében való tájékozódásban.

2. Tudománytörténeti áttekintés. Az $\dot{y} \int a$ szó összesen négy alkalommal

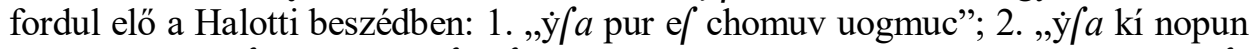
emdul oz gimil/ || twl"; 3. ,i /a e/ num || igg ember mulchotia ez vermut"; 4. ,y/a mend ozchuz iarov \| vogmuc" (MOLNÁR-SIMON 1976: 27). ${ }^{1}$

A következőkben arra törekszem, hogy lehetőleg időrendben és szerzők szerint mutassam be, illetve kommentáljam e kihalt szavunk etimológiájával és értelmezésével kapcsolatos megfejtési kísérleteket.

Tudtommal elsőként SAJNOVICS közölte nevezetes könyvének nagyszombati kiadásában, milyen jelentésű lehetett e szócska. Úgy vélte a szövegkörnyezet alapján, hogy 'bizony; certe, indubianter; sicher, unzweifelhaft' értelmü volt (SAJNOVICS 1770: 5; 1972: 16, 141; 1994: 24), és ezen felfogást a későbbi kutatók közül sokan el is fogadták.

RÉVAI az ysa vagy isa szócskát a kontextusból (szintén) 'certe, vere, profecto' jelentésúként értelmezte, és etimológiai magyarázattal is kísérletezett (RÉVAI 1803/2014: 97). SZINNYEI ez utóbbit okkal utasította el: „Ysa. A Halotti Beszédben előforduló ysa szót RÉVAI [...] az észt vissist 'gewiss, wahr' és a lp. vissast 'certo' szóval egyezteti. Ez a szó megvan a finnben is: vissi 'certus, fidus,

* É. Kiss KATALIN e tanulmány szerzőjével egyidejüleg írt cikket ugyanerről a témáról, amelynek címe: Isa. Kutatómunkája lényegét tekintve azonos eredményre vezetett, mint ami a jelen cikkben olvasható. Megegyeztünk, hogy a szerzők egyidejűleg, de más-más folyóiratban jelentetik meg a két írást. Az övé a Magyar Nyelvőr 140/3. számában tétetik közzé (2016: 303-305).

${ }^{1}$ A dolgozatban közölt nyelvi adatok a forrásokban találhatók betühív másolatai. Gyakran hivatkozom az UEW.-re, ezért az obi-ugor nyelvjárások rövidítéseit az ott alkalmazottak szerint közlöm.

Magyar Nyelv 112. 2016: 269-283. DOI: 10.18349/MagyarNyelv.2016.3.269 
verax, probus; gewiss, sicher, zuverlässig': - csakhogy mind a három kölcsönvétel a svédből (viss), s így ezek az ysa-val nem hozhatók kapcsolatba, jóllehet hasonlítani eléggé hasonlítanak hozzá" (SZINNYEI 1879: 263, még vö. SSA. 3: 462b, gewi $\beta$ : KLUGE 2002: 356a).

A CZUCZOR-FOGARASI-féle szótár is 'bizony' jelentést tulajdonított e szónak (CzF. 3: 123).

HUNFALVY az egyik közeli rokon nyelvünkben, az osztjákban vélt megfelelöt találni: ,izi 'bizony' (régi magyar isa): levija izi tarmal 'a' szolgának bizony elég', adïm jug jim tiïpsa izi an verl 'rossz fa jó gyümölcsöt bizony nem terem," (HUNFALVY 1875b: 17), de nem füzött magyarázatot ezen közléséhez.

KORDA (1887: 175) a 'bizony' jelentéssel is számolt, magát a szót a magyarból magyarázta: „lehetségesnek látszik a szót fölbontani e két elemre $i$-sza. Nézzük e két alkotó részt külön-külön. [Bekezdés.] A -sza mint némely szók végén előforduló toldalék ismeretes az ilyenekböl: monddsza, fogdsza, addsza sat. magas hangú alakban is fogdsza, addszi. [Bekezdés.] Ha az ysá-t kettévesszük, az első tagul ott maradó $y$ - a közelre mutató névmást juttatja eszünkbe ezekben $i$-tt, $i$-gy, i-nnen, $i$-m, $i$-lyen, $i$-de sat. Az a kérdés tehát, hogy az ysa y-je nem egyéb, mint a közelre mutató névmás” (KORDA 1887: 176). „... a szétválasztás ellen alaki szempontból tehető ellenvetések nem olyan természetüek, hogy e föltevést már a priori képtelenségnek mutatnák. E szerint a fölött, hogy az ysa-beli y- és a mutató névmások $i$-je csakugyan azonosnak tekinthető-e, magát a HB. szövegét kell biróul fölhívnunk. E szöveg pedig meglehetősen approbálja ez azonosságot. Előre kell még bocsátani, hogy ha az ysa-beli y csakugyan mutató névmás, akkor az egész ysa szónak jelentése körülbelül annyi mint: 'íme, így, ilyeté n ké p p en '" (KORDA 1887: 177; kiemelés az eredetiben, H. L.).

SZARVAS (1887: 218) KORDA magyarázatát elhárította: az isza olvasatot kizártnak tartotta, és azt is tévesnek minősítette, hogy az $e$ mutató névmás és az igékben adatolt -sza partikula összetételéből (vö. monddsza, fogdsza, addsza) forrott volna egybe, mert a -sza csak igékhez járulhat. Az ezen szót tartalmazó mondatok közül a harmadikba és a negyedikbe (ifa el num igg ember mulchotia ez vermut; y (a mend ozchuz iarov vogmuc) szerinte nemigen illik az 'íme' jelentés, legjobb latin ekvivalensének az enim ('mert, ugyanis, mindenesetre, valóban, bizonyára') szót tartotta. KORDA magyarázatának bírálatát pedig ekképpen összegezte: „Ez utóbbi megkisérlett magyarázat után is tehát ott állunk, a hol eddig voltunk. Az ysa marad továbbra is annak, a mi eddig volt, rejtvénynek" (SZARVAS 1887: 218-219).

SZINEK (1899) egyértelmünek minősítette, hogy szavunk ugyanazt a jelentést hordozza, mint a latin enim. SIMONYI (1907: 429, 1. jegyzet) meggyőzőnek látta ezt az értelmezést (még vö. SIMONYI 1889: 160), és etimológiai ötlettel is előrukkolt: „A rokon nyelvekben találunk is hangzásra és jelentésre hasonló szócskákat: vogul ossa, $\bar{a} s$ 'hogyne, persze' (NyK. 21: 315) és osztják »izi: 'bi-

${ }^{2}$ Ez téves forrásközlés. Talán a következő vogul szók jöhetnének itt számításba: $\mathrm{N}$ ās $s_{2}$ 'hát | nun', asä 'de, viszont | doch, hingegen', N os-sa 'natürlich', amelynek alapszava a $\mathrm{N} \bar{a}_{2}$, LM LU $\mathrm{P} \mathrm{K} \bar{o} s, \mathrm{~T}$ ås, ăs 'és, szintén, megint [...] | auch, noch wieder [...]' (M-WWb. 51b, 392a); úgy 
zony’ (régi magyar isa)«, mint már HUNFALVY észrevette osztják szótárában" (SIMONYI 1907: 429, 1. jegyzet). Nem sokkal később másik etimológiai ötletet adott elő: „Én új egyeztetést ajánlok, ezt sem tudom kétséget kizárva bebizonyítani, de nézetem szerint helyesebb nyomra vezet. Az óbolgárban van egy ješa, eša indulatszó, amely óhajtást fejez ki, 'utinam, vajha' [...] Ez olyan feltünően hasonlít a HB. isa szavához, hogy bízvást ezzel egynek vehetjük, ha föltesszük, hogy a régi szlávságban is volt 'bizony' jelentése s csak ebből fejlödött a 'vajha' jelentés. Ez olyan föltevés, melynek alig áll valami útjában. - (Megjegyzem, hogy a ješa eredete ismeretlen...)" (MARIÁNOVICS [SIMONYI] 1911: 349). MELICH (1911: 409-410) határozottan elutasítja, cáfolja MARIÁNOVICS etimológiáját, és eredetét tekintve továbbra is megfejtésre váró szónak minősíti.

SzARVASra (1887: 217) hivatkozva közli ZoLNAI (1894: 64): az isa „Jelentése 'bizony' vagy 'ugyanis', lat. enim".

TÓTH (1907: 429) szerint az ysa jelentése 'ecce', vagyis 'íme'.

MELICH (1908: 8-9) a 'bizony' jelentés mellett állt ki.

Jóval később ORBÁN GÁBOR egy obskúrus etimológiai ötletre hívta föl a figyelmet: „Az isa szónak új magyarázatát adja BuJNÁK PÁL [...] azt igyekszik bizonyítani, hogy a HB. isa szava a szláv iže, mai že 'hogy' szóból származik. Szerinte a szót izsa alakban kell olvasni”" (ORBÁN 1934: 109). Ez a bizonyos BUJNÁK volt az, aki a finnugor nyelvek, köztük a magyar igekötőit mindenáron a szlávból valóként akarta magyarázni (BUJNÁK 1928), és akinek erről a dolgozatáról BÁRCZI lakonikusan és eufemisztikusan csak így nyilatkozott: „BUJNÁK müve [...] hemzseg a naiv tévedésektől" (BÁRCZI 1982: 125). BUJNÁKnak az ORBÁN által ismertetett állítását - nagyon finoman szólva - én is legfeljebb csak naiv tévedésnek minősíthetem.

BUJNÁK képtelenségét helyettesítendő ORBÁN is előadott egy etimológiai javaslatot: „Az alábbi elgondolások talán közelebb visznek bennünket a helyes megfejtéshez. [Bekezdés.] A szó jelentése 'bizony, íme, mert' [...] Hasonló jelentése van a régi nyelvben a maga kötőszónak is. A NySz. ${ }^{3}$ szerint e kötőszónk jelentése 'cum tamen, quamquam; und doch, zwar', de többször használják a 'bizony, ugyan' jelentésben is [...] Tudjuk, hogy a maga eredetileg visszaható névmás volt, amely gyakran nyomosító szereppel fordult elő, s idővel a mondat tartalmából megengedő kötőszói szerepet értettek rá [...] [Bekezdés.] Ha már most a maga kötőszónak ezeket az alkalmazásait nézzük és összehasonlítjuk a HB-beli ysa alkalmazásaival, azt fogjuk látni, hogy minden nehézség nélkül, egész természetességgel mondható a régi maga a még régibb isa helyén [...] [Bekezdés.] Mármost van a vogulban egy visszaható névmás, amelynek alakja

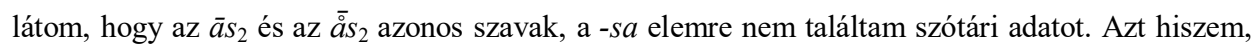
hogy KANNISTO szótárában is - tévedésböl - elkülönítették egymástól ezen szó nyelvjárási változatait: TJ às, TČ ås, P VN VS $\bar{o} s$, LO $\bar{o} s$, So $\bar{s} s$ 'und, auch; noch; mehr; wieder, wiederum | ещё, опять' (K-WWb. 101a), KU ås, ås, KM ås, åsa, KO ås sa 'so, nur so, für sich (in Ruhe), umsonst, unnützerweise; eben (wie); ledig', P LU $\dot{o} s$ 'schon, bereits; noch | уже' (K-WWb. 101a); a -sa elemre itt sem találtam szótári adatot.

${ }^{3}$ NySz. 1: 1613. 
emlékeztet a mi isa kötőszónkra. Ez a középlozvai vogul åsä, amelyről MuNKÁCSI (Vog. Nyelvjárások 109. 1.) ${ }^{4}$ a következőket mondja: »Külön 'ipse' jelentésü névmás: täkw-åsä, pl. khop täkw-åsä pal khžlps 'a ladik maga magától repedt meg' [...] Ez a åsä nyilván a 3. személyü birtokosragot tartalmazza végzetében; alapszava pedig a 'maga' jelentésü finn itse vogul megfelelöje« [...] A vogul névmással talán együvé tartozik a vogul ås 'szintén, megint, még is, hát, bizony' $[\ldots]$ valamint ennek osztják megfelelöje: ås 'is, szintén, még' stb. [...] [Bekezdés.] Ha helyes nyomon vagyunk, akkor az ysa tkp. annyi mint 'maga', vagyis végződése a 3 . személy jele: alapszavának mássalhangzóját valószínüleg $s$-nek kell olvasnunk [...] [Bekezdés.] Jelentésében pedig ugyanazt a fejlödést mutatja, mint amilyent fentebb a maga névmásnál láttunk és ugyancsak ilyen fejlődés alapján használatos nyomósító jelentésben a vogulban is a középlozvai nyomatékosított személyes névmás, a täkw 'ő maga', amelyről ezt írja MuNKÁCSI: „A középlozvaiban 'ő hadd menjen!' így hangzik: tän täkw mini! 'ők ketten hadd (tkp. maga) menjenek!': tän täkw miniji!; 'ők (többen) hadd menjenek!': tan tank minət. Ugyane kifejezés járja a pelymi és kondai vogulban is... " (Vog. nyelvj. 110$)^{5}$ [...] [Bekezdés.] Isa szavunk tehát - ha fejtegetéseink helyesek egy ősi visszaható névmásnak 3. személyü alakja és így elemeinek összetételében is, jelentésében is teljesen megfelel maga névmásunknak, és ugyanazt a jelentésfejlődést is mutatja, mint maga névmásunk" (ORBÁN 1934: 110-111).

ORBÁN szerint tehát az ysa 'maga' jelentésủ nyomatékosító elem lett volna, amely szerinte etimológiailag azonos lenne a középlozvai vogul åsä-val. Az ORBÁN (1934: 110-111) által idézett MUNKÁCSI-féle (1894: 109) „finn itse vogul ås-" összevetés nyilvánvalóan téves etimológiai ötlet, miként természetesen az ORBÁN által ezekhez vont vog. ås 'szintén, megint, még, is, hát, bizony', és osztj. ås 'is, szintén, még' sem egyeztethetö a vog. åsä tövével, a finn itse 'maga' obiugor megfelelöi ugyanis ezek: vog. So is 'der wirkliche, im Sonnenschein sichtbare Schatten des Menschen', osztj. Kr is 'Seele, Geist, ein immaterielles etwas im Menschen' < FU *iće *iśe 'Schatten; Schattenseele' (UEW. 1: 79).

A nagy vogul szótárak nem tartalmaznak $a s$-, $o s$-féle névmást. A MUNKÁCSI által névmás gyanújába vett åsä: täkw-å. - $a \ddot{a}$ eleme valóban sg. 3. személyü birtokos személyjel, az ås pedig minden bizonnyal a vog. N K ås, LM P T ăš, LU aš 'felület, szín, felszín, arc | Fläche, Oberfläche, Antlitz, Gesicht' (M-WWb. 390b-

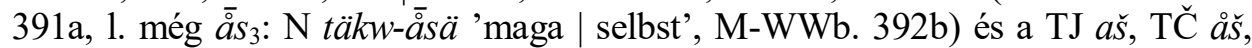

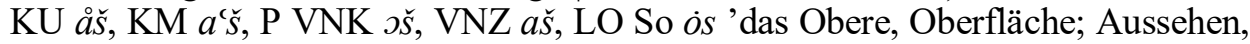
Gesicht' (K-WWb. 101ab) szóval azonos. E szó osztják megfelelője pedig a V Vj

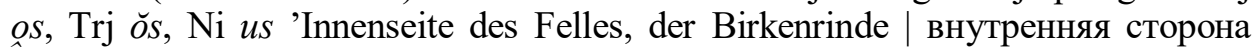
шкуры, берёсты; Haut, Oberfläche', O os 'Epidermis' (DEWOS. 190, 1556); az osztj. Kaz wQš 'Innenseite des (bearbeiteten) Felles | внутренняя сторона шкуры (Kaz)', O os 'Epidermis; untere Schicht des Felles' (DEWOS. 1556) szócikk Kaz tagjának hangalakját $(\breve{s}-)$ alighanem a nyugati vogul nyelvjárások szava befolyá-

\footnotetext{
${ }^{4}$ MuNKÁCSI 1894: 109.

${ }^{5}$ MuNKÁCSI 1894: 110.
} 
solhatta. - Nyomatékos személyes névmási összetétel tagjaként a vog. LM ås̆ másodlagos 'Antlitz, Aussehen, Gesicht' jelentése folytán volt alkalmas. Ehhez vö. orosz лицио 'Gesicht; Person', ukrán лище́ 'Gesicht, Wange; Vorderseite; Person' (VASMER 1953-1958. 2: 49, 1964-1973. 2: 506), még vö. orosz лик II. 'Antlitz; лицо; изображение лица (на иконе)' (VASMER 1953-1958. 2: 41, 1964-1973. 2: 495). - Ennek az obi-ugor szópárnak - ORBÁNnal (1934: 110-111) ellentétben - természetesen nincsen semmi köze sem a most idézendő obi-ugor kötőszókhoz sem, vö. vog. $\mathrm{N} \bar{a}_{2}$, ås, os, LM LU P K $\overline{o s} s$ T ås, às 'szintén, megint, még, is, hát $\mid$ auch, noch wieder, und, und noch, abermals' (M-WWb. 392a), TJ às, TC $\stackrel{a}{a} s$, P VN VS $\bar{o} s$, LO $\bar{o} s$, So $\bar{\jmath} s$ 'und, auch; noch; mehr; wieder, wiederum | ещё, опять' (K-WWb. 101a) ${ }^{6} \sim$ osztj. V VT Vj Trj J os, DN KoP Kr us 'ещё, noch; опять (VT); уже, schon; dennoch (KoP Kr)' (DEWOS. 189).

PAIS (1942: 162) mind a négy mondatban 'bizony'-ként értelmezte az ysá-t.

MÉSZÖLY szerint az isa értelme: 'íme'. Megkísérelte ezt szemantikailag és etimológiailag (stílustörténetileg) is igazolni: „Az isá mint 'ecce' jelentésü mutatószó, olyan alkalmazású, mint az íme (vagy ímé). Az efféle mutatószó végén, mint az íme (im-e!), ugyanolyan indulatszó van, mint az itt-e!, ott-a!, ez-e!, az-a!, ihol-e!, a hol-a! stb. mutatószavakon. Az isá szót is így kell tehát elemeznünk: $i s-a ́$, s ennek végső á-ja mutató értékü indulatszó. Az is- és -á rész egymástól eltérő hangrendje is mutatja, hogy az isá két szónak az összetétele: is + á! A bibliai stílusba beleillenek az 'íme', 'és ímé, 's íme' értelmü és hangulatú mondatkapcsolók. Az is szó az és szóval azonos eredetü, egyik a másiknak alakváltozata. Az ismét is eredetibb és-még-ből lett, az ésmég-ből pedig ismég > isőg > sőg változatokon át a mai sőt lett. Így meg tud változni századok folyamán az és alakja, mikor összetett kötőszónak előtagjává olvad be. Ugyanannak az embernek a beszédében él a sőt is, és is anélkül, hogy az illető beszélő érezné, hogy a $s o ̋ t$-beli $s$ azonos az és > is-sel; így a HB. írója is mondhatott isá-t anélkül, hogy tudta volna, hogy annak és része azonos lehet azzal az és-sel, mely megvan a HB.-ben a mai és értelmében is, a mai is értelmében is, az á rész pedig azonos az oz-beli $o$ elemmel. [Bekezdés.] Az ysa megmagyarázásához nemcsak a latin forrásszöveg ecce szavát vettük figyelembe, hanem azt is, hogy az 'íme, és ímé, s íme' értelmü és hangalakú mondatkapcsolók beleillenek a magyar bibliai stílusba is. Ez a szempont nem általában nyelvtörténeti, hanem stílustörténet i" (MÉSZÖLY 1955: 176-177, 1956: 126-127); kiemelés az eredetiben, H. L.). BÁRCZI határozottan cáfolta ezt a feltevést: „MÉSZÖLY szerint [...] a szó jelentése 'íme', s szerkezete is párhuzamos ezzel, mint ës $\sim$ is a!, im e!, azaz első tagja az es, is nyomatékosító szó, második pedig a mutató névmásnak - mely öszszetett szó: $a+z$, két azonos jelentésủ mutató névmásból áll - első tagja. A magyarázat szellemes, de közel sem meggyőző. Már a föltett jelentést is nehéz levezetni a tagok jelentéséből 'szintén az' $\rightarrow$ 'íme az'. De a HB.-ben az az névmás mindig $o$ magánhangzót tartalmaz: oz, ozchuz, viszont az yła mindig $a$-val van írva. A magyar szót tehát ismeretlen eredetünek kell tartanunk, s ezért jelentése, mon-

\footnotetext{
${ }^{6}$ Ehhez 1. a 2. jegyzetet.
} 
datbeli szerepe is bizonytalan” (BÁRCZI 1982: 35-36). Továbbá: „Jelentése is bizonytalan, csak a HB.-ben fordul elő, mégpedig négyszer, és ez előfordulások alapján úgy látszik, hogy indulatszó, kikövetkeztetett jelentése: 'íme', esetleg 'bizony'. Egy másik föltevés szerint magyarázó, esetleg okhatározó kötőszó volna, mely a latin enim-nek felelhetne meg" (BÁRCZI 1982: 35, 1. még BÁRCZI 1975: 86).

A magyar nyelv nagy etimológiai szótárai ekképpen foglalták össze az $\dot{y} / a$ val kapcsolatos, elkészültükig megszületett, valószínűnek vélt állásfoglalásokat: 1. „'íme; siehe da | bizony, wirklich' [...] [Bekezdés.] Bizonytalan eredetü. Talán összetett szó: az is-nek és vagy az az mutató névmás $a$ változatának, vagy esetleg az $a^{1}$ mutató értékü indulatszónak az összetapadásával keletkezhetett; vö. ott a!, $a z a$ ! - Az $i$ - mutató névmási tő és a -sza nyomatékosító elem összetételeként való magyarázata, a maga névmással való egybevetése, valamint szlávból való származtatása téves” (TESz. 2: 237a). - 2. „'siehe da; wirklich' • Unbest Urspr, evtl Kompos $\otimes$ Viell aus is 'und' (Var von $\rightarrow$ és od $\rightarrow i s)+a\left(\rightarrow a z^{1}\right.$ od $\rightarrow a ́)$; synt unbest. Das W kommt nur in HB vor; die genaue Bed ist deshalb unbest, evtl durch die Ma der HB bedingt. Die Gleichsetzung des ersten Glieds mit $\rightarrow$ és und $\rightarrow$ is stößt auf die Schwierigkeit, daß beide $\mathrm{W}$ in diesem SprDenkmal nur in der Form $e \int$ vorkommen. Die Deutung, daß das zweite Glied mit einem DemPron $\left(\rightarrow a z^{1}\right)$ od mit einer Interj $(\rightarrow a ́)$ identisch sei, ist aus chronologischen Gründen problematisch •" (EWUng. 1: 625b).

Ezek az állásfoglalások voltaképpen a szótárak főszerkesztőjének nézetével azonosak: „E szövegrészek isa vagy isá kiejtésű módosító szava körül régtől fogva értelmezési eltérések mutatkoznak, s ezek az eltérések nemcsak magának e szócskának, hanem mondatbeli funkciója folytán a vele kapcsolatos szövegrészeknek is többé-kevésbé eltérő tartalmat kölcsönöznek. Néhány egyéb értelmezés mellett, mint például az 'ugyanis', 'ihol csak' stb. komolyabban két lehetöség: a 'bizony' és az 'íme' került eddig számításba", és itt elég bő irodalmi utalások találhatók (BENKŐ 1980: 290-291). Természetesen ezt tükrözi történeti grammatikánk is: „Már az egyszerü módosítószók között is találkoztunk olyanokkal, amelyek korai ősmagyar vagy korábbi összetett szavakból értékelődtek át. Az összetétel folyamata végigkíséri a szófaj történetét, de nagyobb jelentőségre csak a kései ómagyar kortól tesz szert. Az ősmagyar kor végén, illetve a korai ómagyarban - különböző valószínüségi fokon - a következö összetett lexémákat, szoros kapcsolatokat tehetjük fel: [Bekezdés.] Nyelvemlékes adataink vannak - igaz, csak a HB.-ből - az isá-ra [...] Az 'íme, bizony' jelentésü kihalt isa valószínüleg az is partikulával nyomatékosított $A$ ! mutató névmási mondatszóból keletkezett" (JUHÁsZ 1991: 510).

A. Molnár (2005: 24) 'bizony (íme)' és 'bizony' értelmet tulajdonít e szavunknak (nála: isä).

Csak a kutatástörténeti teljesség végett említem meg, hogy GULYA is kitért futólag az $\dot{y} / a$ lehetséges tagolására, amely szerinte így lenne helyes: I-sà, $i$-sa, de nem indokolta eljárását, sem értelmezésével, sem eredetével nem foglalkozott (GULYA 2007: 338, 340-341). 
Tudománytörténeti áttekintésemet egy fölöttébb furcsa ötlet ismertetésével zárom le. Egy jó szándékú kívülálló úgy érezte, hogy közhírré kell tennie, mit hisz e szavunkról. Csak azért térek ki az általa összesen négy írásban is publikált fantáziadús elképzelésekre, mert meglepő módon patinás tudományos folyóirataink egyike juttatta hozzá a közlés lehetőségéhez. Hasonló szakértelemmel szerintem akár hamuból vagy kávézaccból is ki lehetne olvasni $\dot{y}$ /a szavunk történetét:

„A felvetett problémák közül a legsúlyosabbnak azt tartom, hogy az isa jelentése bizonytalan, az 'íme' és a 'bizony' jelentést csupán a szövegösszefüggés alapján következtették ki. Én az isa utótagjára vonatkozó első TESz.-változattal értek egyet, de azon túlmegyek, s a teljes összetételt tovább elemzem. Ily módon jobbíthatónak tartom az isa szófejtését, valamint a hozzá tartozó szövegrészek értelmezését. [Bekezdés.] Az isá-t elhomályosult összetételnek fogom fel. Szerintem az $i+s+a$ elemekből áll. - Az $i$ elem a közelre mutató $e z$ névmási tő $i$ - változata, amely az itt, ide, ime, eme stb. szavakban (ma már elhomályosultan) van jelen. - Az $a$ elem az $a z$ távolra mutató névmási tő $a$ - változata (vagy maga az $a z$ névmási tő), amely megtalálható az ott, oda, ám, ama stb. szavakban (szintén elhomályosultan). - Az $s$ nem egyéb, mint a ma is gyakori kapcsolatos kötőszavunk, az is, melynek esetenként nyomósító szerepe is van. [Bekezdés.] Az isa elhomályosult mellérendelő összetétel jelentése tehát 'ez és az (= mindkettö)' lehetett" (GAÁL 1999: 260). - E szerző kárhoztatja, hogy az elődök a szövegkörnyezetből próbálták megfejteni a szócska jelentését. Az általa megalkotott etimológiai magyarázatból levezetett jelentés azonban semmiképpen sem illik a szövegbe.

E szerző az $\dot{y} \int a$-nak a szakirodalomban feltételezett jelentései kapcsán írja, hogy azok bármelyike is ,csak részben állja meg a helyét, ugyanis az egy szóból álló értelmezés már eleve nem lehet kifogástalan, mivel abból kimaradt az isa $s$ eleme. [Bekezdés.] Az isa az adott szövegrészekben közöltekkel egyezően 'ez és az szemmel láthatóan igaz', 'a valóságnak megfelelően igaz' és 'való igaz' értelmezései, valamint az ím és ám szerkezetben az ámnak 'bizony igaz' jelentése között fennálló szemantikai összefüggés arra mutat, hogy az ím és ám szerkezet jelentésileg is pótolhatja az isát" (GAÁL 2000: 399-400). - Ezt az értelmezést ugyanúgy minősítem, mint az előző passzusban szereplő idézetben lévőt.

„Az eddigieken kívül a $V C V$-rendszer további elemekkel is bővülhetett, így a magánhangzóból álló mutató névmási tő palatális és veláris változatának a hozzátoldó kapcsolatos $s$ 'és' kötőszóval szerkesztett összetételével: $e+s+a \sim$ $i+s+a$ 'ez és az' (vö. HB.), ase asi 'az és ez', asa, ese 'ez és az, ez és ez'. A $C$ elem ezekben a $s$ kötőszó. A fölsoroltakon kívül természetesen lehetett még többféle nyíltabb-zártabb vokálisú alak is. Mind a $V C V$ fölépítésü kikövetkeztetett változatokban, mind a HB.-ből adatolt isa alakokban - alaktani fölépítésükből következően - közelre is, és távolra is irányul a rámutatás. A HB.-ben megőrződött isa $z$ nélküli mutató elemei ezen kívül még a szövegben közöltek szemmel látható, vagyis nyilvánvaló, 'valóban igaz' voltát is jelzik. Az élőbeszédben tágabb értelemben, minden olyan közlésben lehetett a fenti alakokat használni, amikor két főnévnek vagy mondatnak igaz valóságát akarták kiemelni, hangsúlyozni. - Állításomat megerősíti a HB. ez, $a z \sim$ 'az' mutató névmásai, valamint 
az isa $z$ nélküli $i, a$ mutató névmásai között meglevő alakbeli különbözőség. Ebből a megkülönböztető írásmódból a névmásnak egymástól eltérő mondatbeli funkciójára lehet következtetni: arra, hogy ez ez, az »csak « mutató szerepü, az $i$ $e$ és $a$ viszont nyomatékosabb, rámutató szerepü" (GAÁL 2001: 381). - E „továbbfejlesztett" ötlet semmivel sem teszi értelmesebbé a Halotti beszéd szóban forgó mondatait, sőt! (L. még az előző két passzushoz füzött kommentárt.)

„...az elöadottak alapján arra lehet gondolni, hogy a HB.-béli is a szóösszetétel az ősi rendszernek csupán egyik alakválto zat a [kiemelés az eredetiben, H. L.]. Vagyis úgy hiszem, hogy ha a nyelvemlékes korszakból - valami »csoda« folytán - még elökerülne isa szó, az is a HB.-béli isa 'ez és az' jelentését viselné, és annak a szerkezeti fölépítését mutatná. Eltérés legföljebb a közelre vagy távolra mutatástól függően - és annak sorrendje szerint - a vokálisok váltakozó hangalakjában, az író nyelvjárásának megfelelően mutatkozna (pl. asi 'az és ez')" (GAÁL 2001: 381). - Csak abban értek egyet e szerzővel, hogy ilyen csodára nem számíthatunk.

Azt hiszem, e naivságok konglomerátumára aligha szükséges több szót vesztegetni.

3. Az $\dot{y} / a$ eredetéről. A tudománytörténeti előzmények számba vétele után térek át arra, milyen etimológiai magyarázatot látok reálisnak $\dot{y} / a$ szavunk eredetére vonatkozóan. Fentebb már említettem, hogy egykoron HUNFALVYnak volt egy ötlete, amelyet nem fejtett ugyan ki (HUNFALVY 1875b: 17), de én azt mégis nagyon is valószínünek értékelem. Ezen ötletre utalt MARIÁNOVICS [SIMONYI] (1911: 349), de nem nyilatkozott arról, helyesli-e vagy sem. Mivel én helyesnek találom, megpróbálom igazolni, miért helyes. HUNFALVY ugyanis valószínüleg leginkább csak a hangalaki hasonlóság, vagyis a szókezdő $i$ elemet tartalmazó osztják és magyar alakok (adverbiumok) szinte teljes hangtani azonossága és a szónak SAJNOVICS által feltételezett 'bizony; certe, indubianter' jelentése miatt gondolt az egyezésre; vö. ,izi 'bizony' (régi magyar isa): levija izi tarmal 'a' szolgának bizony elég', adïm jug jim tiïpsa izi an verl 'rossz fa jó gyümölcsöt bizony nem terem"' (HUNFALVY 1875b: 17). Az ugyanott található adatokat, amelyek az iméntivel szorosan összefüggnek, már külön szócikkbe sorolta be: ,izi (i-si egy-az) azon, izagat (i-sagat) egy-ként, egyszer-int, mind, izit (i-sit) ugyanaz, izikem (i-si-kem) ugyanannyi”. Ezek legalább részben a grammatikai leírásban is megtalálhatók: izagat ultïna 'minden által, folyvást', mur izagat edliset 'a nép mind kimenének' (HUNFALVY 1875a: 101, 108-109), az $i$ elem nélküli alakok (névutók) ezek: sagat, sajït 'szerint, -ért, -kor', pora sagat 'az idő szerint', voh sagat 'pénzért', jolta sagat 'után', tolta sagat 'onnan', jilta sagat 'alatt, alá' (HUNFALVY 1875a: 105).

Ezek a HUNFALVY közölte VOLOGODSZKI-féle adatok a következő későb-

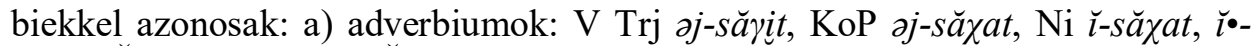

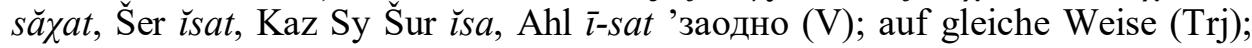

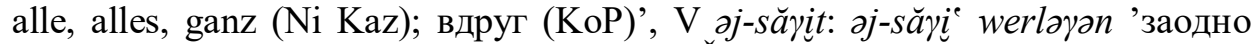

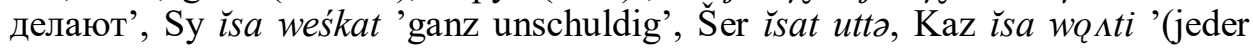


seiende) каждый $\mid$ jeder alle' (DEWOS. 18-19, 1311), Ahl $\bar{l}$-sag்at 'in derselben Richtung', ì-sagat, ìsat utta (zuweilen auch ohne utta) 'ganz, alles' (AHLQVIST

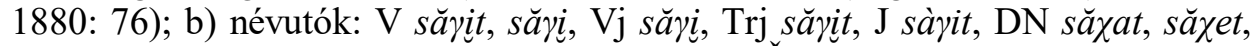

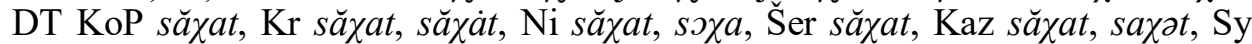

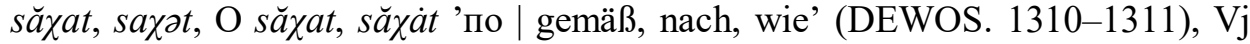

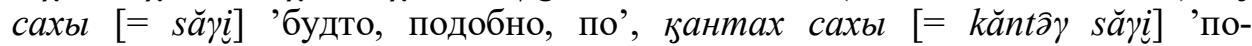
хантыйски' (MOGUTAEV 1996: 248). Feltűnő, hogy a nyugati nyelvjárási ada-

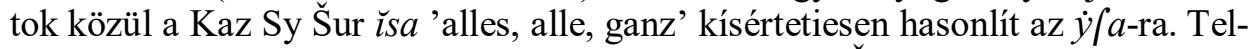

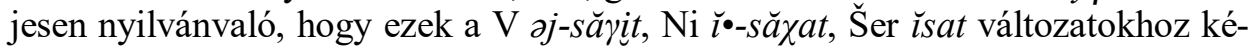
pest erősen csonkult adatok, amelyek alapszava a *să

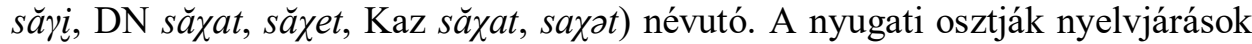

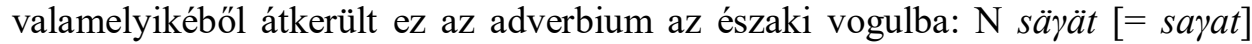
'után | nachdem' (< osztják, M-WWb. 509a).

STEINITZ kétkedve vonta ehhez az osztják szócsaládhoz az osztj. O săxa 'nach kurzer od. einiger Zeit | спустя короткое время' adverbiumot (DEWOS. $1310,1311)$. Nem értek egyet a bizonytalankodással, mivel valamiképpen az azonosítást, egységesítést és általánosítást kifejező obi-ugor adverbiumok az 'idő, időszakasz', 'vminek a részei' típusú, oszthatóságot, tagolhatóságot kifejező szókból (is) alakulnak. Ilyenek pl. az a) osztják V VT Vj Trj J os, DN KoP Kr us 'ещё, noch; опять (VT); уже, schon; dennoch (KoP Kr)' > NazT әj-us, әj-usa 'заодно, одновременно', Ser ‘̆j-ŏs 'gleichzeitig' (DEWOS. 189); Trj pič, DN $\mathrm{Kr}$-piš, Ni Kaz pǔš, O pus 'Faden; „Schicht” (d. h. Fell, Futter od. Überzug)

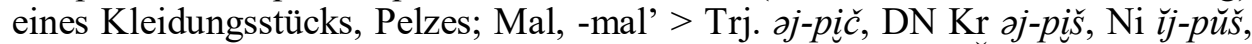

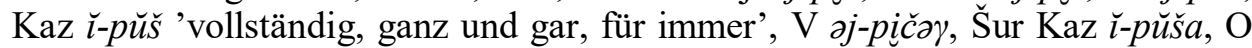
$i$-рusá 'на всегда | für immer' (DEWOS. 18, 1089-1090); valamint b) vogul T

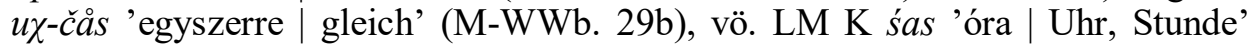
(M-WWb. 591a); LU äkw-šit 'egyszerre | zu gleicher Zeit' (M-WWb. 29b), KU

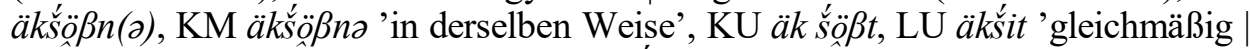

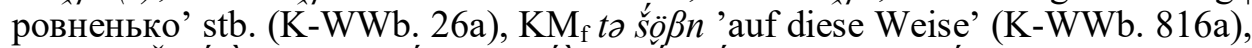

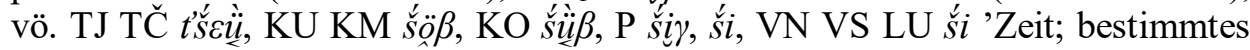
Maß; so viel wie; bestimmte Menge; Art; etwa' (K-WWb. 815a).

Az itt felsorolt, szóösszetételből alakult adverbiumok előtagja az '1' jelentésű számnév. Elég sok ilyen található a nagy osztják és vogul szótárakban, pl. DEWOS. 18-19, M-WWb. 28a-29b, K-WWb. 24a-27b.

A most idézendő vogul adverbium két szempontból is igen figyelemre méltó:

a) A LU $\varepsilon k s ̌ a \gamma, t l$ 'alle(s) auf dieselbe Weise | всё одинаково, всё ровно' $(\mathrm{K}-\mathrm{WWb}$. 26a) $\varepsilon k$ - előtagja természetesen azonos az $\varepsilon k$ '1' jelentésủ számnévvel (K-WWb. 23b), a šay,tl utótag pedig csak ebből az egy nyelvjárásból és csak ebben az egy összetételben van adatolva: LU ekša , tl" (K-WWb. 713a).

b) A ša , $t l$ utótag nyilvánvalóan az - $l$ instrumentalisragot tartalmazza, a szótő így a vogulban önállóan nem adatolt *šayat ?*'gemäß, nach, wie', amely az

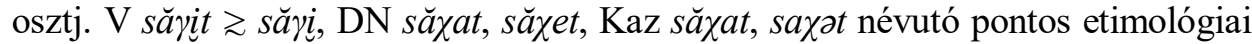
megfelelője. Ezek közös, obi-ugor alapnyelvi előzménye *šă tebb idézett osztj. O săza 'nach kurzer od. einiger Zeit' adverbium azt sejteti, 
hogy a legtávolabbi obi-ugor előzmény *šă y volt, ebböl pedig az instrumentalisi funkciót is ellátó ${ }^{*} t$ locativusrag csatlakozásával jött létre a $* s \breve{a} \gamma \triangleleft t{ }^{7} \mathrm{Az}$ osztj. $s-\sim$ vog. $\breve{s}$ - megfelelés természetesen nem akadálya az egyeztetésnek, vö. pl. osztj. V sat, Trj såt, DN sot, Ni Kaz sot, O sat '100' vog. TJ šç $t$, KU šāt, P šẹt, So sāt 'id.' ( ma. száz < Ug *šata < FU *śata [UEW. 1: 467] > finn sata), miként az osztj. (-) $s-\sim$ magyar $\left(* *_{s}->\right)-s-$ sem, feltehető ugyanis vagy egy ősmagyar kori *̌s $\sim *_{s}$ váltakozás, pl. ,sövény : szö (MSzFE. 3: 582b-583a, 792b793a; UEW. 1: 471: FU *śäne), sömör : szem stb." (TESz. 3: 508; még vö. sömör: TESz. 3: 579b; UEW. 1: 479: *śilmä [de ez utóbbiban csak a szëm említtetik meg]), ször sörény (< Ug *šärz-r3 vagy *šäkrз 'Haar', vö. UEW. 2: 886), vagy még inkább egy , $\mathrm{U} / \mathrm{FU} *_{\dot{S}}^{\prime}>\mathrm{Ug} *_{S} \sim *^{\prime}$ ” fonémahasadás következtében létrejött szóhasadás (erről l. alább).

A ma. $s^{-} \sim \operatorname{vog} . s^{-} \sim$ osztj. $s$ - megfelelés valószínüleg a most ismertetendő módon magyarázható. Az ugor alapnyelv az U/FU ${ }^{*} s,{ }^{*} s,{ }^{*} s ̌$ szibilánsrendszert örökölte, mely a következő változásokon ment át:

1. U/FU $*_{s} \times *_{s}>\mathrm{Ug} *_{s}$,

2. $\mathrm{Ug} *_{s}>* \vartheta$,

3. $\mathrm{U} / \mathrm{FU} * \dot{s}>\mathrm{Ug} *_{S} \sim *_{s}$,

4. $\mathrm{Ug} *_{S}>\mathrm{Ug} *_{S} \sim *_{s}$.

A 3. lépésben bekövetkezett ugor alapnyelvi fonémahasadás legtöbbször talán szóbelseji palatalizált mássalhangzó hatására bekövetkezett depalatalizáció

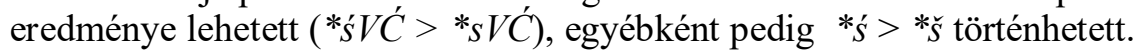

Ennek eredményeként az ugor alapnyelvben az U/FU $*_{S}, *_{s}^{\prime}, *_{s}$ szibilánsok helyét az Ug $*_{s}, *^{5}, * \vartheta$ foglalta el. Az ugor nyelvek ezeknek a (szókezdő) szibilánsoknak a következő szabályszerü, de nem egyöntetű megfelelési rendszerét mutatják (vö. HONTI 1999: 124-130; az obi-ugor adatokat egyszerüsítés végett itt fonematikus átírásban közlöm):

1. Ug $*_{s}>$ ma. $s z \sim \mathrm{OUg} *_{s}>$ vog. $s \sim$ osztj. $s$, pl.:

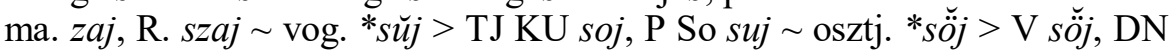
sĕj, Ni Kaz sĭj, O sij (<< Ug *soje < FU *'śoje 'Ton, Laut, Stimme', vö. UEW. 1: 482-483),

ma. szél $\sim$ vog. *sīl $>$ KU So sēl $\sim$ osztj. $*_{\text {sil }}>\mathrm{V}$ O sil $\left(<<\mathrm{Ug} *_{\text {sel3 }}\right.$ 'Rand', vö. UEW. 2: 887),

2. Ug $*_{\breve{s}}>$ ma. $s \sim s z \sim$ OUg $*_{\breve{s}}>$ vog. $*_{\grave{s}}>\check{s} \sim s \sim$ osztj. $*_{\breve{s}}>s$, pl.:

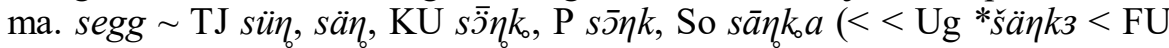
*śänk3 'der Hintere, Arsch', vö. UEW. 1: 472).

ma. szëm sömör vog. *šăm > TJ KU P šäm, So sam osztj. *sem > V Ni Kaz O sem (<< Ug *šem < *śilmä 'Auge', vö. UEW. 1: 479),

${ }^{7}$ A locativus, az adessivus és a superessivus ragja eszközhatározói funkciót is betölthet (vö. LiIMOLA 1963: 113, 115, 117), pl. vog. K ton ten-t lo joutam 'azon az áron lovat veszek' (BEKE 1905a: 81, 1905b: 15, vö. tèn 'ár; pénz', M-WWb. 646a, még vö. LiIMOLA 1963: 118), osztj. M lajam-ən 'fejszével' (vö. lajam 'fejsze'; RADANOvics [RÉDEI] 1961: 33, 59, még vö. LiIMOLA 1963: 117), finn kirjoitan kynä-llä 'ceruzával/tollal írok', észt vitsu-l kasvatama 'pálcával nevelni'. 
ma. ször $\sim$ sörény vog. *̌š $\bar{a} r>\mathrm{TJ} \check{s} \bar{a} r, \mathrm{KU} \check{s} \bar{\partial} r, \mathrm{P} \check{s} \bar{\partial} r, \mathrm{LO} s \bar{a} \gamma r$, So $s \bar{a} \gamma r a(<$ $<\mathrm{Ug} * \check{s} \ddot{a} \gamma 3-r 3$ vagy *šäkr3 'Haar', vö. UEW. 2: 886),

3. Ug $*_{s}>$ ma. $s z \sim$ OUg $*_{\check{s}}>\operatorname{vog} . *_{\check{s}}>\check{s} \sim s \sim$ osztj. $*_{\check{s}}>s$, pl.:

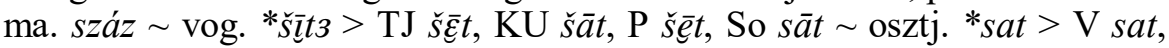
Trj såt, DN sot, Ni Kaz sst, O sat '100' (<< Ug *šata < FU *śata 'hundert', vö. UEW. 1: 467).

Az Ug $*_{s}->$ ősma. $*_{s ̌-} \sim *_{s-}(>$ ma. $s-\sim s z-)$ kettősség kialakulása pedig bizonyosan elö- vagy ősmagyar nyelvjárási különbségben leli magyarázatát.

Az osztják és a vogul adatokhoz mind hang-, mind jelentéstanilag jól illeszkedik a Halotti beszéd $\dot{y} / a$ formájú adverbiuma. E szó $\dot{y}=i$ elemében szintén az '1' számnév rejtőzik, tudvalévőleg a magyarban is vannak az '1' számnévvel létrejött adverbiumok: egyaránt, egyáltalában, egyáltalán, egyelöre, egyúttal. Az '1' számnév ugor kori történetéröl adott leírásom érthetővé teszi e számnévnek ezen adverbiumba történt beépülését: „Die Zahlwörter '1' in den ugrischen Sprachen lassen sich [...] von dem Rekonstrukt *ike, *üke ableiten. Im Urungarischen bzw. in der obugrischen Grundsprache ging der Wandel $*_{-} k$ - $>*_{-} \gamma$ - vor sich, welches neben $* \breve{u} \mathrm{zu} * \gamma_{0}$ labialisiert wurde, zumindest in der obugrischen Grundsprache. In der obugrischen Sprachgeschichte sind in mehreren Fällen Schwankungen $*_{\gamma_{0}} \gtrsim *_{\gamma} \gtrsim$ *j bekannt, denen zufolge nach einem palatalen Vokal im Früh-Urostjakischen leicht ein Wandel $* \check{\partial} \gamma_{0} / * \breve{e} \gamma>* \breve{e j}$ eintreten konnte” (HONTI 1993: 80). „Auch im Urungarischen kann mit dem Wandel $*_{i k 3} / * \ddot{u} k_{3}>*_{i \gamma 3} / *_{\ddot{u} \gamma_{3}}$ gerechnet werden, wo auf Einfluß des benachbarten Palatalvokals oberer Zungenstellung das $*_{\gamma} / *_{\gamma_{0}}$ durch *j abgelöst wurde (oder dies durch teilweise Assimilation eintrat), was sich im Ungarischen zu $d^{\prime}$ [= gy] entwickelt haben mag" (HONTI 1993: 81). Úgy gondo-

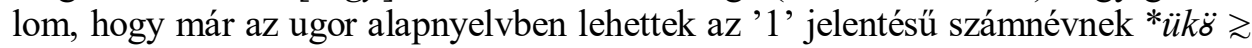
$* \ddot{u} \gamma_{0} \ddot{o} \sim * \ddot{u} j \ddot{\delta}$ változatai. E számnevünkben bekövetkezett $\mathrm{Ug} * \ddot{u}>$ ma. $i$ változást egyértelmüen igazolják első adatai, például éppen a Halotti beszédben megtalálható ig és igg (1. TESz. 1: 716, 1. továbbá NySz. 1: 572, ëggy).

A $-\int a(=-s a)$ utótag pedig a következő módon alakulhatott ki: Ug *ša

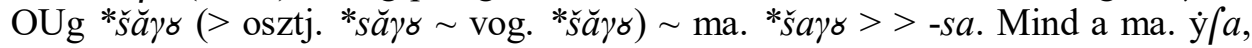
mind az északi osztj. ̌̌sa, issat deetimologizálódott, tehát elvesztette egyes nyelvtörténeti elemeinek eredeti forrásszavával fennállott nyilvánvaló kapcsolatát.

Összegezve a fentieket: az eddigi etimologizálási kísérletekkel ellentétben a Halotti beszéd $\dot{y} / a$ 'bizony' szavát ugor alapnyelvi összetételként értelmezem: „'1' számnév + 'amint' névutó" > 'egészen, teljesen' adverbium > 'bizony'

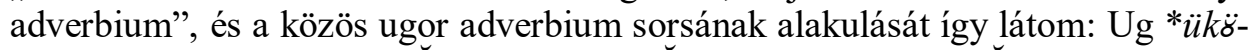

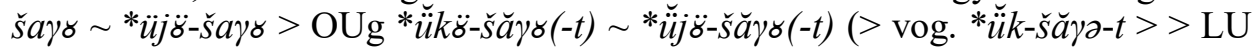

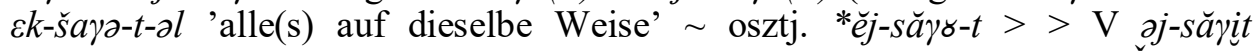

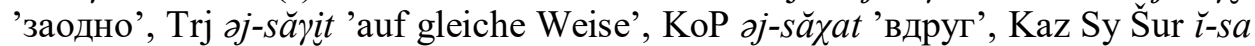

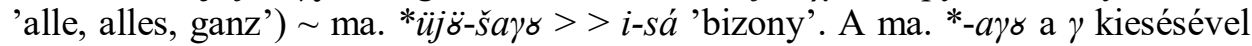
szükségszerüen hosszú magánhangzóvá, vagyis -á-vá lett, azaz az $\dot{y}$ /a olvasata bizony isá lehetett, miként MÉSzÖLY (1955: 177, 1956: 127) és alternatív lehetőségként BENKÖ (1980: 290-291) vélte.

Ezzel kiderített ugor kori nyelvi újításaink száma ismét emelkedett eggyel. 
A nyelvtörténeti folyamatok kiderítése, az etimológiai összefüggések feltárása gyakran a mozaikkép kockáinak megkeresését, egymáshoz illeszthetőségük megállapítását jelenti. Az $\dot{y} / a$ hátterének kinyomozása is ezt szemlélteti.

Kulcsszók: Halotti beszéd, ugor, magyar, vogul, osztják, etimológia, szemantika.

\section{Hivatkozott irodalom}

Ahlqvist, August 1880. Über die Sprache der Nord-Ostjaken. Sprachtexte, Wörtersammlung und Grammatik. Forschungen auf dem Gebiete der uralaltaischen Sprachen. Dritter Theil. Finnische Literaturgesellschaft, Helsinki.

BÁRCZI GÉZA 1975. A magyar nyelv életrajza. 3. kiadás. Gondolat, Budapest.

BÁRCZI GÉZA 1982. A Halotti Beszéd nyelvtörténeti elemzése. Nyelvészeti tanulmányok 24. Akadémiai Kiadó, Budapest.

BEKE ÖDÖN 1905a. A vogul határozók. Nyelvtudományi Közlemények 35: 71-100.

BEKE ÖDÖN 1905b. A vogul határozók. Különlenyomat a Nyelvtudományi Közlemények 35. kötetéböl. Budapest.

BENKÖ LORÁND 1980. Az Árpád-kor magyar nyelvü szövegemlékei. Akadémiai Kiadó, Budapest.

BujnÁK, PÁVOL 1928. Praefixa verbalia v jazykoch ugrofinských a zvlášte v mad'arskom. Nákladem Filosofické University Karlovy, Praha.

CzF. = CZUCZOR GERGELY - FOGARASI JÁNOS, A magyar nyelv szótára 1-6. Emich Gusztáv / Athenaeum, Pest / Budapest, 1862-1874.

DEWOS. $=$ STEINITZ, WOLFGANG, Dialektologisches und etymologisches Wörterbuch der ostjakischen Sprache. Lieferung 1-15. Akademie-Verlag, Berlin, 1966-1993.

EWUng. = Etymologisches Wörterbuch des Ungarischen 1-2. Hrsg. BENKÖ LORÁND. Akadémiai Kiadó, Budapest, 1993-1995.

GAÁL IMRE PÉTER 1999a. yfa. Szófejtési kísérlet. Magyar Nyelvőr 123: 260.

GAÁl IMRE PÉTER 1999b. Helyreigazítás az yfa szófejtéséhez. Magyar Nyelvőr 123: 372.

GAÁl IMRE PÉTER 2000. Az isa kihalása után ím(e)s ám szerkezet (magyarázatkísérlet). Magyar Nyelvőr 124: 399-400.

GAÁl IMRE PÉTER 2001. Az isa és az ösmagyar kori *VCV fölépítésủ mutató névmási rendszer. Magyar Nyelvőr 125: 381-382.

GULYA JÁNOS 2007. Egy európai magyar nyelvemlék. In: MATICSÁK SÁNDOR szerk., Nyelv, nemzet, identitás. A VI. Nemzetközi Hungarológiai Kongresszus (Debrecen, 2006. augusztus 22-26.) elöadásai 1-2. Nemzetközi Magyarságtudományi Társaság, Debrecen-Budapest. 2: 331-342.

HonTI LÁszLó 1993. Die Grundzahlwörter der uralischen Sprachen. Bibliotheca Uralica 11. Akadémiai Kiadó, Budapest.

HonTI LÁsZló 1999. Az obi-ugor konszonantizmus története. Studia Uralo-Altaica. Supplementum 9. JATE, Szeged.

HuNFALVY PÁL 1875a. Az északi osztják nyelv Vologodszki fordításainak és oroszosztják szótárának alapján tekintettel mind Castrén déli osztják grammatikájára, 
mind a Reguly hozta szó-jegyzékre s eredeti osztják énekekre. Nyelvtudományi Közlemények 11/1: 1-236.

Hunfalvy PÁL 1875b. Szó-tár. Nyelvtudományi Közlemények 11/2: 1-226.

JAKUBOVICH EMIL - PAIS DEZSÖ 1929. Ó-magyar olvasókönyv. Tudományos Gyüjtemény 30. Danubia, Pécs.

JUHÁSz DEZSÖ 1991. A módosítószók. In: BENKÖ LORÁND szerk., A magyar nyelv történeti nyelvtana. I. kötet. A korai ómagyar kor és elözményei. Akadémiai Kiadó, Budapest. 501-513.

KLUGE, FRIEDRICH 2002. Etymologisches Wörterbuch der deutschen Sprache. 24. Auflage. Walter de Gruyter, Berlin - New York.

KoRda ImRe 1887. Ysa. Magyar Nyelvőr 16: 175-178.

$\mathrm{K}-\mathrm{WWb}$. = KANNISTO, ARTTURI - EIRAS, VUOKKO - MOISIO, ARTO, Wogulisches Wörterbuch. Gesammelt und geordnet von A. K., bearbeitet von V. E., herausgegeben von A. M. Lexica Societatis Fenno-Ugricae 35. Kotimaisten Kielten Keskuksen Julkaisuja 173. Société Finno-Ougrienne - Kotimaisten Kielten Keskus, Helsinki, 2013.

LiImola, Matti 1963. Zur historischen Formenlehre des Wogulischen. I. Flexion der Nomina. Mémoires de la Société Finno-Ougrienne 127. Suomalais-Ugrilainen Seura, Helsinki.

MeliCH JÁNOS 1908. Révai Miklós első magyarázata a Halotti Beszédről. Magyar Nyelv 4: $1-12$.

MELICH JÁnOs 1911. Isa. Magyar Nyelv 7: 409-411.

MARIÁNOVICS MiLÁN [SIMONYi Zsigmond] 1911. Szláv jövevényszók. Magyar Nyelvőr 40: 348-350.

MÉSZÖLY GEDEON 1955. A Halotti Beszéd néhány szavának stílustörténeti módszerü megfejtése. (Mutatvány a „Nyelvtörténeti séták nyelvemlékeink között” címü müböl.) Magyar Nyelv 51: 176-182.

MÉSZÖLY GEDEON 1956. Ómagyar szövegek nyelvtörténeti magyarázatokkal. Tankönyvkiadó, Budapest.

Mogutaev, М. К. [МогУтАев, М. К.] 1996. Хантыйско-русский словарь (васюганский диалект). Томский государственный университет, Томск.

A. MolnÁR FERENC 2005. A legkorábbi magyar szövegemlékek (olvasat, értelmezés, magyarázat, frazeológia). Nyelvi és müvelödéstörténeti adattár. Kiadványok 8. Debreceni Egyetem Bölcsészettudományi Kar, Klasszika-filológiai Tanszék, Debrecen.

MolnÁR JÓZSEF - SiMON GYÖRGYI 1976. Magyar nyelvemlékek. Tankönyvkiadó, Budapest.

MSzFE. = A magyar szókészlet finnugor elemei. Etimológiai szótár 1-3. Főszerk. LAKÓ GYÖRGY. Akadémiai Kiadó, Budapest, 1967-1978.

MuNKÁCSI BERNÁT 1894. A vogul nyelvjárások szóragozásukban ismertetve. Magyar Tudományos Akadémia, Budapest.

M-WWb. = MunKÁCSI BERNÁT - KÁLMÁN BÉLA, Wogulisches Wörterbuch. Akadémiai Kiadó, Budapest, 1986. 
NySz. = SZARVAS GÁBOR - SiMONYI ZSIGMOND, Magyar nyelvtörténeti szótár a legrégibb nyelvemlékektöl a nyelvújításig 1-3. Hornyánszky, Budapest, 1890-1893.

OrbÁN GÁBor 1934. Isa. In: BeKE ÖDÖN - BENEdeK MArCEll - Turóczi-Trostler JózSEF szerk., Emlékkönyv Balassa Józsefnek, a Magyar Nyelvőr szerkesztőjének 70. születése napjára. Ranschburg Gusztáv Könyvkereskedése, Budapest. 109-111. PAIS DEZSŐ 1942. A Halotti Beszéd olvasása és értelmezése. Magyar Nyelv 38: 159-162. RADANOVICS [RÉDEI] KÁROLY 1961. Északi-osztják nyelvtan. Nyelvtudományi Értekezések 31. Akadémiai Kiadó, Budapest.

RÉVAI MiKLÓS 1803/2014. Magyar irodalmi régiségek. Antiquitates literaturae Hungaricae. Fordította C. VLADÁR ZsuzSA. ELTE Magyar Nyelvtudományi és Finnugor Intézet - OSZK, Budapest.

SAJNOVICS, JOANNIS 1770. Demonstratio idioma ungarorum et lapponum idem esse. Typis Collegii Academici Societatis Jesu, Tyrnaviæ.

SAJNOVICS, JOHANNES 1972. Beweis, daß die Sprache der Ungarn und Lappen dieselbe ist. Veröffentlichungen der Societas Uralo-Altaica. Band 5. Otto Harrassowitz, Wiesbaden.

SAJNOViCs JÁNOS 1994. Demonstratio. Bizonyitás. A magyar és a lapp nyelv azonos. Bibliotheca Regulyana 2. ELTE, Budapest.

SimONYi Zsigmond 1889. A magyar nyelv. A müvelt közönségnek. Első kötet. A magyar nyelv élete. Révai testvérek, Budapest.

[SimONYi Zsigmond] 1907. [Szerkesztői lábjegyzet TóTH BÉLA Ysa. Eleve címü cikkéhez.] Magyar Nyelvör 36: 429.

SSA. = Suomen sanojen alkuperä 1-3. Toim. Kulonen, UllA-MAIJA. Suomalaisen Kirjallisuuden Seuran Toimituksia 556. - Kotimaisten Kielten Tutkimuskeskuksen julkaisuja 62. Suomalaisen Kirjallisuuden Seura - Kotimaisten kielten tutkimuskeskus, Helsinki, 1992-2000.

SZARVAS GÁBOR 1887. Ysa. Magyar Nyelvőr 16: 217-219.

SZINEK IZIDOR 1899. Az ysa jelentése. Magyar Nyelvőr 28: 103-104.

SZINNYEI JÓZSEF 1879. Révai magyar-ugor nyelvhasonlítása. Nyelvtudományi Közlemények 15: 248-286.

TESz. = A magyar nyelv történeti-etimológiai szótára 1-3. Főszerk. BENKÖ LORÁND. Akadémiai Kiadó, Budapest, 1967-1976.

TóTH BÉla 1907. Ysa. Eleve. Magyar Nyelvőr 36: 429.

UEW. = Uralisches etymologisches Wörterbuch 1-2. Hrsg. RÉDEI KÁROLY. Harrassowitz - Akadémiai Kiadó, Wiesbaden-Budapest, 1986-1991.

VASMER, MAX 1953-1958. Russisches Etymologisches Wörterbuch 1-3. Carl Winter Universitätsverlag, Heidelberg.

VASMER, MAX [ФАСМЕР, МАКС] 1964-1973. Этимологический словарь русского языка 1-4. Прогресс, Москва.

ZOLNAI GYULA 1894. Nyelvemlékeink a könyvnyomtatás koráig. Magyar Tudományos Akadémia, Budapest. 


\section{Research history and etymology of the word isa from the Funeral Sermon}

As opposed to former attempts at its etymology, the present author takes the word $y / a$ (= isa) 'indeed' from Sermo super sepulchrum to be a compound coined in Proto-Ugric: '1' (numeral) + 'as soon as' (postposition) > 'totally, fully' (adverb) > 'indeed' (adverb), and sees the

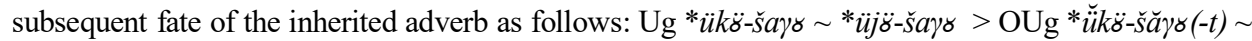

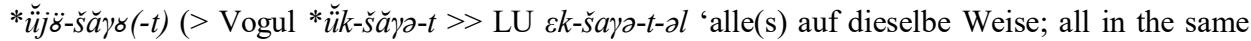

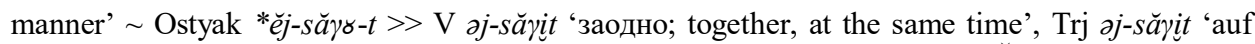

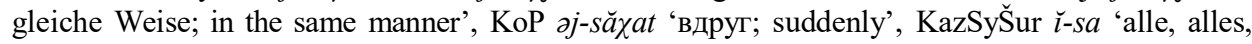
ganz; all, every, totally'), $\sim$ Hungarian *üjö-ša $>>\dagger i$-sá 'indeed'.

Keywords: Funeral Sermon, Proto-Ugric, Hungarian, Vogul, Ostyak, etymology, semantics.

HONTI LÁSZLÓ

Károli Gáspár Református Egyetem

MTA Nyelvtudományi Intézet 